\title{
Novel synthetic bisbenzimidazole that targets angiogenesis in Ehrlich ascites carcinoma bearing mice
}

\author{
Rangaswamy Roopashree ${ }^{a}$, Chakrabhavi Dhananjaya Mohan ${ }^{a}$, Toreshettahally Ramesh Swaroop ${ }^{\text {, }}$ \\ Swamy Jagadish ${ }^{a}$, Byregowda Raghava ${ }^{a}$, Kyathegowdanadoddi Srinivas Balaji ${ }^{\mathrm{b}}$, Shankar Jayarama ${ }^{\mathrm{b}}$, \\ Basappa ${ }^{c}$, Kanchugarakoppal Subbegowda Rangappa ${ }^{a, *}$ \\ ${ }^{a}$ Department of Studies in Chemistry, University of Mysore, Manasagangotri, Mysore 570 006, India \\ ${ }^{\mathrm{b}}$ Department of Biotechnology, Teresian College, Mysore 570 011, India \\ c Laboratory of Chemical Biology, Department of Chemistry, Bangalore University, Bangalore 560 001, India
}

\section{A R T I C L E I N F O}

Article history:

Received 20 January 2015

Revised 16 March 2015

Accepted 1 April 2015

Available online 11 April 2015

\section{Keywords:}

Bisbenzimidazole

Ehrlich ascites tumor

Angiogenesis

Antiproliferative

Vascular Endothelial Growth Factor

Micro vessel density

\begin{abstract}
A B S T R A C T
Cancer is a leading cause of death in developed countries and second cause in developing countries. Herein we are reporting the synthesis of novel bisbenzimidazole derivatives and their anticancer properties. Among the newly synthesized bisbenzimidazoles, 3-(4-flurophenylsulfonyl)-1,7-dimethyl-2-propyl$1 \mathrm{H}, 3 \mathrm{H}$-2,5-bibenzo[d]imidazole (FDPB) presented as a potent antiproliferative agent against HeLa, HCT116 and A549 cells with selectivity over normal Vero cells $\left(\mathrm{IC}_{50}>50 \mu \mathrm{M}\right)$. Additionally, we evaluated the efficacy of lead compound against Ehrlich ascites tumor (EAT) bearing mice for its antitumor and antiangiogenic properties. Our lead compound significantly reduced the cell viability, body weight, ascites volume and downregulated the formation of neovasculature and production of Vascular Endothelial Growth Factor (VEGF).
\end{abstract}

๑) 2015 Elsevier Ltd. All rights reserved.
Cancer is a most ravaging disease threatening globally with a leading mortally rate in developed countries. ${ }^{1}$ Various types of cancers have been identified which affects different organs and they are broadly grouped under the category of carcinoma, sarcoma, lymphoma or leukemia based on the type of tissue origin., ${ }^{2,3}$ Most common striking features of all types of cancer is uncontrolled cell proliferation, antiapoptosis, enhanced angiogenesis, genomic instability and metastasis. ${ }^{4}$ The broad range of devastating characteristics of the cancer makes it a very good therapeutic target for designing the small molecules. In cancer drug discovery programme, researchers have contributed many novel synthetic compounds as anticancer drugs.

Benzimidazoles are the most prominent heterocycles with diverse biological functions. ${ }^{5-7}$ Multiple previous reports have suggested that benzimidazoles to be very good cytotoxic agents against different types of cancer cell lines. ${ }^{8}$ Recently bisbenzimidazole conjugates have been reported to target mitochondria in cancer cells and induce their antiproliferative activity by caspase

Abbreviation: FDPB, 3-(4-flurophenylsulfonyl)-1,7-dimethyl-2-propyl-1H,3H2,5-bibenzo[d]imidazole.

* Corresponding author. Tel.: +91 08212419661.

E-mail address: rangappaks@gmail.com (K.S. Rangappa). dependent apoptosis. ${ }^{9}$ In addition, bisbenzimidazoles bind to minor groove of the DNA to instigate its anti-proliferative effect and many DNA minor groove binders have entered clinical trials in cancer treatment. ${ }^{10,11}$ Furthermore, bisbenzimidazoles possess topoisomerase- $1^{12}$ and serine protease inhibition, ${ }^{13}$ antiviral, ${ }^{14}$ antileishmanial, ${ }^{15}$ and several other biological properties. ${ }^{16}$ In continuation of our effort in designing small molecules as anticancer agents, bisbenzimidazoles drawn our interest to synthesize the novel bisbenzimidazoles and evaluate their anticancer activity both in vitro and in vivo. ${ }^{17-24}$ Among the newly synthesized compounds, we selected the most potent cytotoxic compound against HeLa (Cervical cancer), HCT116 (Colon cancer), A549 (Lung cancer) and evaluated for its in vivo antitumor and antiangiogenic properties using Ehrlich ascites tumor (EAT) bearing mice.

A mixture of methyl 3,4-diamino-5-methyl benzoate 1, butanoic acid and polyphosphoric acid (PPA) were irradiated in a microwave flask at $150{ }^{\circ} \mathrm{C}$ for 10 min to get methyl 4-methyl-2propyl-1H-benzo[d]imidazole-6-carboxylate 2 . The key intermedi-

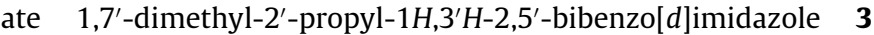
was obtained by the reaction of $\mathbf{2}$ with $\mathrm{N}$-methyl-o-phenylenediamine using PPA at $150{ }^{\circ} \mathrm{C}$ for $12 \mathrm{~h} .{ }^{25}$ Finally, key intermediate 3 was subjected to undergo $\mathrm{N}$-sulfonation with various sulfonyl chlorides 4 to get respective 1,7'-dimethyl-3'-(arylsulfonyl)-2'- 
propyl-1H,3'H-2,5'-bibenzo[d]imidazole 5a-j (Fig. 1A). The structures of all the synthesised compounds were confirmed by spectral and micro analytical analysis. All final compounds showed characteristic triplet between 0.8 and $1.1 \delta$ for methyl protons, triplet around $3.1 \delta$, sextet around $1.9 \delta$ for methylene protons, singlet at $2.0 \delta$ for aryl methyl protons and singlet at $3.9 \delta$ for $N$-methyl protons. The structures and yields of the synthesised compounds are given in Table 1.

FDPB induces its cytotoxic effect in time and dose dependent manner in HeLa cells: We investigated the anti-proliferative effect of newly synthesized bisbenzimidazoles $\mathbf{5} \mathbf{a}-\mathbf{j}$ against the panel of cell lines including HeLa, HCT116 and A549 cells using MTT assay as described previously and $\mathrm{IC}_{50}$ values are tabulated in Table $1 .{ }^{18,26,27}$ We found bisbenzimidazoles $\mathbf{5 d}$ and FDPB having $p$-methoxy- and $p$-flurosulfonyl groups exhibited significant cytotoxicity towards HeLa and HCT116 cells with the $\mathrm{IC}_{50}$ values ranging from $16.7 \mu \mathrm{M}$ to $19.9 \mu \mathrm{M}$. Further, bisbenzimidazoles $\mathbf{5 b}-\mathbf{c}$ bearing tolyl and mesityl sulfonyl groups displayed notable anticancer activity with $\mathrm{IC}_{50}$ values ranging from $20.1 \mu \mathrm{M}$ to $41.6 \mu \mathrm{M}$ against HeLa and HCT116 cells. Compounds $\mathbf{5 h}-\mathbf{j}$ substituted with 2,5-dichlro-, 2-chloro and 2-bromophenylsulfonyl groups were found to be inactive against HeLa cells. On the other hand, most of the new bisbenzimidazole derivatives displayed least antiproliferative activity against A549 and monkey kidney epithelial (Vero) cells up to $50 \mu \mathrm{M}$. Thus compounds with inductively electron releasing methyl groups are good inhibitors over unsubstituted counterparts. Also, strong electron releasing and withdrawing substituents increased the activity. Notably, the activity decreases with decrease in electro negativity of halogen at para position of sulfonyl motif. Finally, halogen substitution at ortho position of arylsulfonyls is ineffective. Despite the fact that all compounds are less potent than standard sorafenib, the structure activity relationship profiles is very interesting. Furthermore, we identified FDPB as potent cytotoxic agent and tested on HeLa cells at indicated dose and time points and found the substantial decrease in viable cells (Fig. 1B). The lead compound FDPB is taken for further in vivo studies.

FDPB interferes with cell cycle and arrest HeLa cells in SubG1 phase: Formation of hypodiploid cells is a hallmark event in cells undergoing apoptosis which can be detected using propidium iodide staining. ${ }^{28}$ We evaluated whether FDPB can effect cell cycle distribution as described earlier. ${ }^{29}$ We found the built up of cells in subG1 phase in the time dependent manner (Fig. 1C). The results confirmed the cytotoxic effect of FDPB.

FDPB significantly decrease ascites volume, body weight and cell viability: We further analysed the effect of FDPB on body weight and ascites volume in the tumor of drug treated and control mice as described earlier. ${ }^{21}$ We observed the significant decrease in the body weight after the administration of FDPB (Fig. 2A and $\mathrm{B})$. Based on this observation, we quantified the ascites volume and results confirmed the decrease of ascites fluid (Fig. 2C). In addition, results of trypan blue assay displayed the substantial

A<smiles>CC#CCCc1nc2c(C)cc(C(=O)OC(C)=O)cc2[nH]1</smiles><smiles>CCCc1nc2c(C)cc(-c3nc4ccccc4n3C)cc2[nH]1</smiles>

B

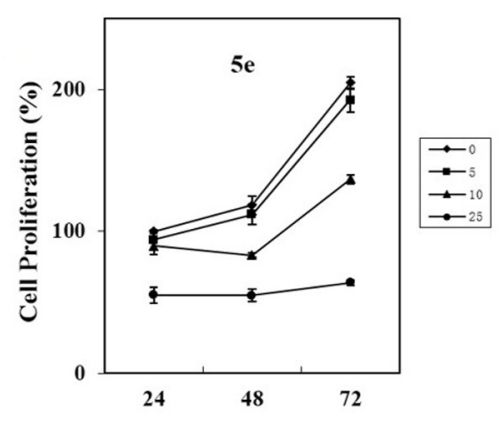

C
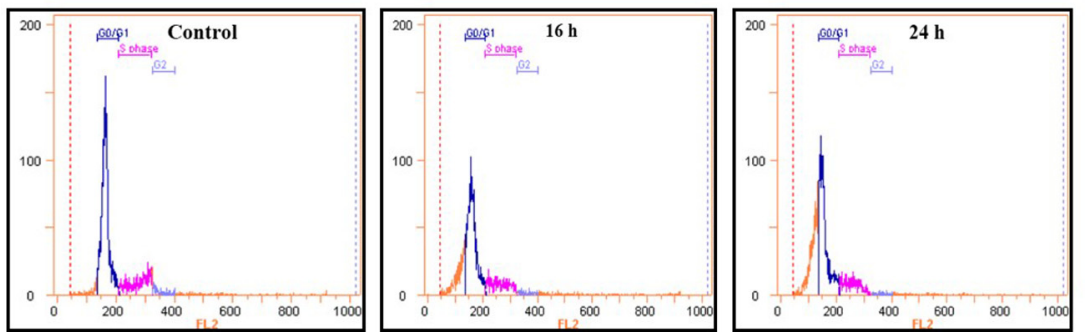

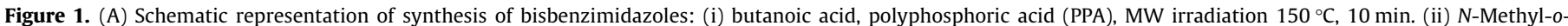

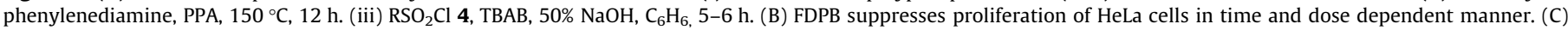
Flow cytometric analysis indicates the arrest of HeLa cells in SubG1 phase in the time dependent manner. 
Table 1

Structures, yield and cytotoxicity $(\mu \mathrm{M} \pm \mathrm{SD}$ ) data of the bisbenzimidazole derivatives $\mathbf{5} \mathbf{a}-\mathbf{j}$

\begin{tabular}{|c|c|c|c|c|c|c|c|}
\hline Sl no & $\mathrm{R}(\mathbf{4}, \mathbf{5})$ & 5 & $\%$ yield $^{\mathrm{a}}$ & HeLa $(\mu \mathrm{M})$ & HCT116 $(\mu \mathrm{M})$ & A549 $(\mu \mathrm{M})$ & Vero $(\mu \mathrm{M})$ \\
\hline 1 & $\mathrm{C}_{6} \mathrm{H}_{5}$ & $5 a$ & 56 & $23.8 \pm 1.6$ & $>50$ & $>50$ & $>50$ \\
\hline 2 & $4-\mathrm{MeC}_{6} \mathrm{H}_{4}$ & $5 \mathbf{b}$ & 83 & $20.1 \pm 3.1$ & $41.6 \pm 4.9$ & $>50$ & $>50$ \\
\hline 3 & $2,4,6-\mathrm{Me}_{3} \mathrm{C}_{6} \mathrm{H}_{2}$ & $5 c$ & 90 & $21 \pm 3.9$ & $29.9 \pm 5.9$ & $>50$ & $>50$ \\
\hline 4 & $4-\mathrm{MeOC}_{6} \mathrm{H}_{4}$ & $5 d$ & 72 & $18.3 \pm 2.1$ & $19.1 \pm 10.1$ & $34.7 \pm 6.3$ & $>50$ \\
\hline 5 & $4-\mathrm{FC}_{6} \mathrm{H}_{4}$ & $\mathbf{5 e}$ (FDPB) & 65 & $16.7 \pm 5.8$ & $19.9 \pm 8.2$ & $32.2 \pm 7.5$ & $>50$ \\
\hline 6 & $4-\mathrm{ClC}_{6} \mathrm{H}_{4}$ & $5 f$ & 67 & $21.4 \pm 5.4$ & $36.8 \pm 5.4$ & $>50$ & $>50$ \\
\hline 7 & $4-\mathrm{BrC}_{6} \mathrm{H}_{4}$ & $5 g$ & 84 & $24.7 \pm 5.7$ & $49.3 \pm 6.5$ & $35.1 \pm 9.1$ & $>50$ \\
\hline 8 & $2,5-\mathrm{Cl}_{2} \mathrm{C}_{6} \mathrm{H}_{3}$ & $5 h$ & 87 & $>50$ & NT & NT & NT \\
\hline 9 & $2-\mathrm{ClC}_{6} \mathrm{H}_{4}$ & $5 \mathbf{i}$ & 62 & $>50$ & NT & NT & NT \\
\hline 10 & $2-\mathrm{BrC}_{6} \mathrm{H}_{4}$ & $5 \mathbf{j}$ & 68 & $>50$ & NT & NT & NT \\
\hline
\end{tabular}

NT-not tested.

a Yield corresponds to the last step of the synthesis.

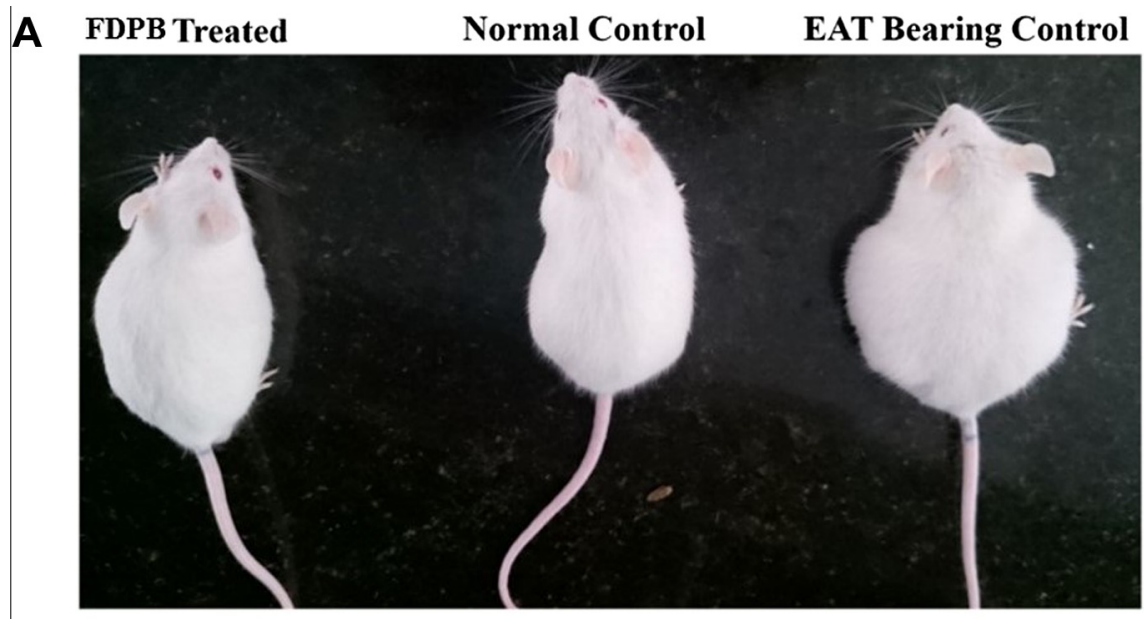

B

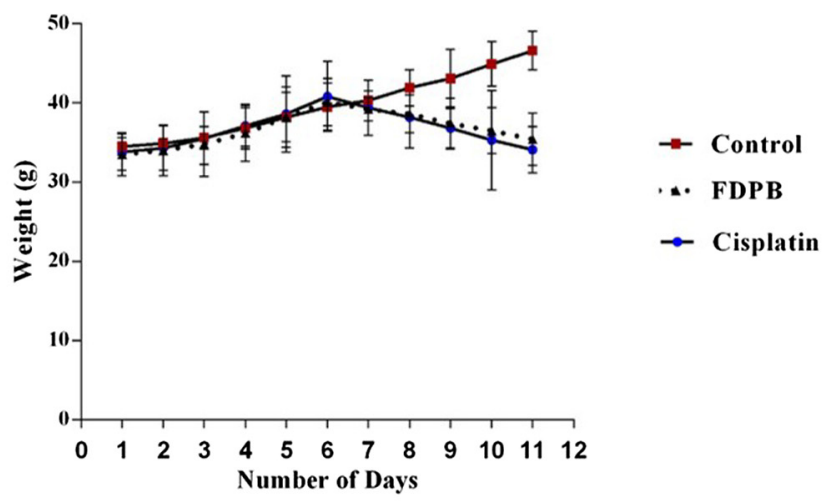

C

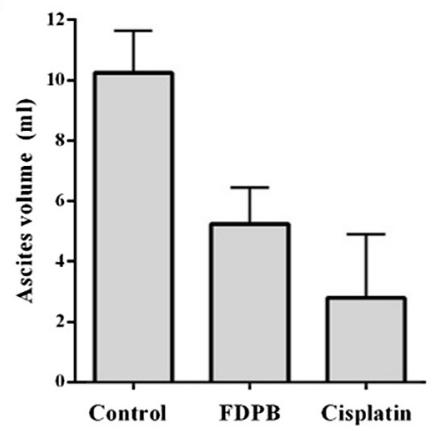

D

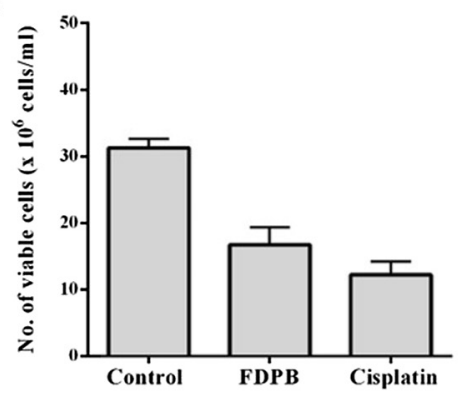

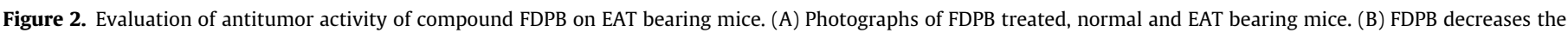

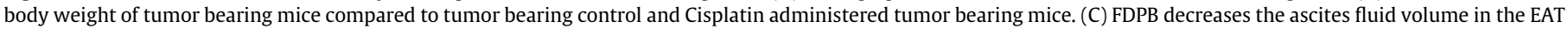
mice. (D) Percentage of viable cell count significantly reduced in FDPB treated mice. 
decrease in number of viable cells in FDPB treated mice (Fig. 2D). This concludes that our lead molecule possess very good anticancer property.

FDPB suppresses angiogenesis in EAT bearing mice: Angiogenesis is associated with tumor expansion by uncontrolled cell proliferation and metastasis. ${ }^{30}$ Therefore inhibition of angiogenesis is a direct measure of increased prognosis. We evaluated whether FDPB can downregulate neovasculature and micro vessel density (MVD) in the peritoneal cavity of EAT bearing mice. Figure $3 \mathrm{~A}$ clearly shows that FDPB notably suppress the peritoneal angiogenesis. Additionally, quantification of MVD in the $\mathrm{H} \& \mathrm{E}$ stained peritoneum tissue displayed significant reduction in the number of micro vessels (Fig. 3B). $8 \pm 2$ vessels/high power field were observed in FDPB treated mice compared with $54 \pm 6$ vessels/ High power field in control mice.

FDPB downregulates the VEGF in Ehrlich ascites tumor: Based on the predominant suppression of peritoneal angiogenesis and MVD, the effect of FDPB on the local production of VEGF in the peritoneal cavities of EAT bearing mice was investigated using ELISA based method. ${ }^{31}$ The levels of VEGF substantially decreased in the lavage fluid to $225 \pm 4 \mathrm{ng}$ in FDPB treated mice (Fig. 3C), In contrast, the levels of VEGF were found to be $2412 \pm 10 \mathrm{ng}$ in the control mice confirming the anti-angiogenic role of FDPB.

FDPB induces apoptosis in Ehrlich ascites tumor cells: Cellular morphological changes, shrinkage and fragmentation of genomic DNA are the hallmark events in the cell undergoing apoptosis. ${ }^{32}$
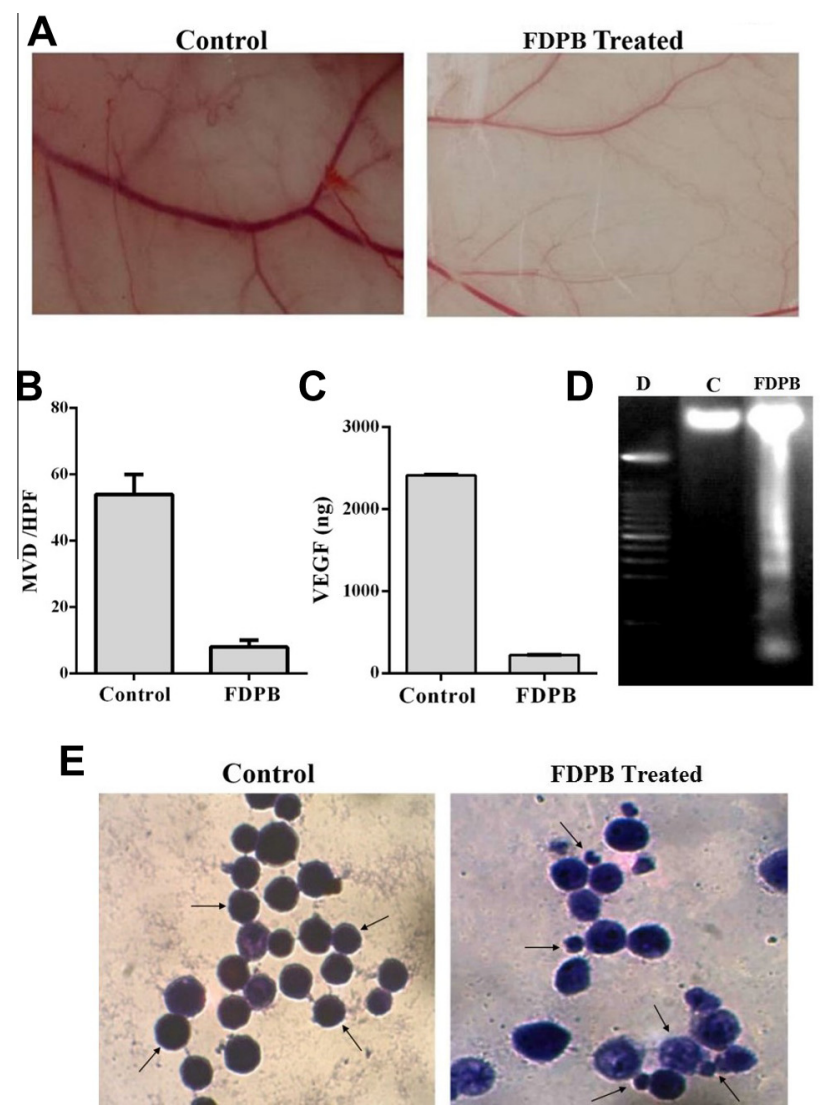

Figure 3. FDPB inhibits neovasculature in EAT bearing mice. (A) FDPB suppress peritoneal angiogenesis in EAT bearing mice. (B) $\mathrm{H} \& \mathrm{E}$ staining of peritoneum of FDPB treated mice displayed the substantial decrease of MVD. (C) Profiling of VEGF in the lavage fluid collected from EAT bearing FDPB treated and control mice. (D) FDPB induces apoptosis in Ehrlich ascites tumor cells and it is demonstrated by DNA fragmentation in FDPB treated mice (D-DNA ladder; C-Tumor control). (E) Morphological changes in cells and formation of apoptotic bodies in EAT cells of FDPB treated mice.
Inhibition of peritoneal angiogenesis encouraged us to investigate whether FDPB can induce its anti-proliferative effect by promoting apoptosis in Ehrlich ascites cells. We performed DNA fragmentation assay to detect the intactness of the DNA in cells treated with our lead compound. The results obtained clearly demonstrate the extensive degradation of genomic DNA and concluding that FDPB induces apoptosis (Fig. 3D). Furthermore, morphological changes of the cells treated with our lead compound was evaluated by Giemsa staining. Microscopic observation of cells stained with Giemsa displayed cell shrinkage, formation of small blebs and apoptotic bodies (Fig. 3E).

In conclusion, an ideal anti-cancer drug should inhibit the proliferation of cancer cells, prevent metastasis, enhance apoptosis and suppress angiogenesis in tumors. ${ }^{33,34}$ Designing and synthesis of novel small molecules that can target cancer cells specifically and inhibiting their proliferation by disrupting the multiple survival signals is a prime challenge in cancer drug discovery. In continuation of our effort to synthesize new anti-cancer agents and considering the contribution of benzimidazole nucleus in the development of various drugs, we herein report the synthesis, characterization, anti-proliferative and anti-angiogenic activity of novel bisbenzimidazole derivatives. Newly synthesized compounds were evaluated for their cytotoxic efficacy against HeLa, HCT116 and A549 cells and lead compound was carried forward for the evaluation of its in vivo antitumor activity. In addition, the lead compound did not display cytotoxicity towards nondiseased (Vero) cells. Linlin and colleagues have demonstrated that bisbenzimidazole derivatives induce cytotoxicity in cancer cells through both death receptor and mitochondria-mediated apoptotic pathways. ${ }^{9}$ Therefore, we are concluding that, our lead compound possibly induce its antiproliferative effect on cancer cells by activating caspases which are known to induce activation of caspase-activated DNases (CAD). The activation of CAD proteins leads to the degradation of genomic DNA into nucleotide oligomers thereby inducing apoptosis of cancer cells. In summary, FDPB proved to be an efficient anticancer agent with a therapeutic potential to combat cancer.

\section{Acknowledgments}

Authors are grateful to Board of Research in Nuclear Sciences (BRNS), University Grants Commission (UGC) and Indo-French Centre for the Promotion of Advance Research (IFCPAR), Government of India for financial support to KSR under the projects vide No. 2009/37/40/BRNS/2266 dated 23-11-2009, F-39-106/2010 (S.R.) dated 24-12-2010 and No. IFC/4303-1/ 2010-11 Dated 22-12-2010. R.R. thank University Grants Commission for Rajiv Gandhi National Fellowship, CDM thank Department of Science and Technology for Innovation in Science Pursuit for Inspired Research fellowship and T.R.S. thank Council of Scientific and Industrial Research for Junior and Senior Research Fellowship.

\section{Supplementary data}

Supplementary data (detailed experimental procedures for the synthesis and the pharmacological investigations) associated with this article can be found, in the online version, at http://dx.doi.org/ 10.1016/j.bmcl.2015.04.010.

\section{References and notes}

1. Jemal, A.; Bray, F.; Center, M. M.; Ferlay, J.; Ward, E.; Forman, D. CA: Cancer J. Clinicians 2011, 61, 69.

2. Berg, J. W. J. Natl Cancer Inst. 1967, 38, 741.

3. Lamb, D.; Pilney, F.; Kelly, W. D.; Good, R. A. J. Immunol. 1962, 89, 555.

4. Khan, I.; Ibrar, A.; Abbas, N. Arch. Pharm. 2014, 347, 1. 
5. Abonia, R.; Cortes, E.; Insuasty, B.; Quiroga, J.; Nogueras, M.; Cobo, J. Eur. J. Med. Chem. 2011, 46, 4062.

6. Townsend, L. B.; Devivar, R. V.; Turk, S. R.; Nassiri, M. R.; Drach, J. C. J. Med. Chem. 1995, 38, 4098.

7. Ries, U. J.; Mihm, G.; Narr, B.; Hasselbach, K. M.; Wittneben, H.; Entzeroth, M.; van Meel, J. C.; Wienen, W.; Hauel, N. H. J. Med. Chem. 1993, 36, 4040.

8. Hranjec, M.; Starcevic, K.; Piantanida, I.; Kralj, M.; Marjanovic, M.; Hasani, M.; Westman, G.; Karminski-Zamola, G. Eur. J. Med. Chem. 2008, 43, 2877.

9. Li, L.; Wong, Y. S.; Chen, T.; Fan, C.; Zheng, W. Dalton Trans. (Cambridge, England: 2003) 2012, 41, 1138.

10. Yang, Y. H.; Cheng, M. S.; Wang, Q. H.; Nie, H.; Liao, N.; Wang, J.; Chen, H. Eur. J. Med. Chem. 1808, 2009, 44.

11. Mann, J.; Baron, A.; Opoku-Boahen, Y.; Johansson, E.; Parkinson, G.; Kelland, L R.; Neidle, S. J. Med. Chem. 2001, 44, 138.

12. Singh, M.; Tandon, V. Eur. J. Med. Chem. 2011, 46, 659.

13. Yeung, K. S.; Meanwell, N. A.; Qiu, Z.; Hernandez, D.; Zhang, S.; McPhee, F. Weinheimer, S.; Clark, J. M.; Janc, J. W. Bioorg. Med. Chem. Lett. 2001, 11, 2355.

14. Roderick, W. R.; Nordeen, C. W., Jr.; Von Esch, A. M.; Appell, R. N. J. Med. Chem. $1972,15,655$.

15. Mayence, A.; Pietka, A.; Collins, M. S.; Cushion, M. T.; Tekwani, B. L.; Huang, T. L.; Vanden Eynde, J. J. Bioorg. Med. Chem. Lett. 2008, 18, 2658.

16. Hu, L.; Kully, M. L.; Boykin, D. W.; Abood, N. Bioorg. Med. Chem. Lett. 2009, 19, 1292.

17. Novak, M.; Rangappa, K. S.; Manitsas, R. K. J. Org. Chem. 1993, 58, 7813.

18. Bharathkumar, H.; Paricharak, S.; Dinesh, K.; Siveen, K. S.; Fuchs, J. E.; Rangappa, S.; Mohan, C.; Mohandas, N.; Kumar, A. P.; Sethi, G. RSC Adv. 2014 4,45143 .

19. Bharathkumar, H.; Mohan, C. D.; Ananda, H.; Fuchs, J. E.; Li, F.; Rangappa, S.; Surender, M.; Bulusu, K. C.; Girish, K. S.; Sethi, G. Bioorg. Med. Chem. Lett. 2015.

20. Neelgundmath, M.; Dinesh, K. R.; Mohan, C. D.; Li, F.; Dai, X.; Siveen, K. S. Paricharak, S.; Mason, D. J.; Fuchs, J. E.; Sethi, G. Bioorg. Med. Chem. Lett. 2015, 25,893 .
21. Rangappa, K. S.; Roopashree, R.; Mohan, C. D.; Swaroop, T. R.; Jagadish, S. Asian J. Pharm. Clin. Res. 2014, 7.

22. Anusha, S.; Anandakumar, B. S.; Mohan, C. D.; Nagabhushana, G. P.; Priya, B. S.; Rangappa, K. S.; Basappa, T. C. G. RSC Adv. 2014, 4, 52181.

23. Neelgundmath, M. Dinesh, K. R. Mohan, C. D.; Li, F; Dai, X.; Siveen, K. S. Paricharak, S.; Mason, D. J.; Fuchs, J. E.; Sethi, G. Bioorg. Med. Chem. Lett. 2014.

24. Anusha, S.; Anandakumar, B.; Mohan, C. D.; Nagabhushana, G.; Priya, B.; Rangappa, K. S. RSC Adv. 2014, 4, 52181.

25. Mizuno, C.; Chittiboyina, A.; Patny, A.; Kurtz, T.; Pershadsingh, H.; Speth, R.; Karamyan, V.; Avery, M. Med. Chem. Res. 2009, 18, 611.

26. Mohan, C. D.; Bharathkumar, H.; Bulusu, K. C.; Pandey, V.; Rangappa, S.; Fuchs, J. E.; Shanmugam, M. K.; Dai, X.; Li, F.; Deivasigamani, A.; Hui, K. M.; Kumar, A. P.; Lobie, P. E.; Bender, A.; Basappa; Sethi, G.; Rangappa, K. S. J. Biol. Chem. 2014, 289, 34296.

27. Keerthy, H. K.; Mohan, C. D.; Sivaraman Siveen, K.; Fuchs, J. E.; Rangappa, S.; Sundaram, M. S.; Li, F.; Girish, K. S.; Sethi, G.; Basappa; Bender, A.; Rangappa, K. S. J. Biol. Chem. 2014, 289, 31879.

28. Hsiao, C. J.; Hsiao, G.; Chen, W. L.; Wang, S. W.; Chiang, C. P.; Liu, L. Y.; Guh, J. H.; Lee, T. H.; Chung, C. L. J. Nat. Prod. 2014, 77, 758.

29. Keerthy, H. K.; Garg, M.; Mohan, C. D.; Madan, V.; Kanojia, D.; Shobith, R.; Nanjundaswamy, S.; Mason, D. J.; Bender, A.; Basappa; Rangappa, K. S.; Koeffler, H. P. PLoS ONE 2014, 9, e107118.

30. Vijay Avin, B. R.; Thirusangu, P.; Lakshmi Ranganatha, V.; Firdouse, A.; Prabhakar, B. T.; Khanum, S. A. Eur. J. Med. Chem. 2014, 75, 211.

31. Deepak, A. V.; Salimath, B. P. Biochimie 2006, 88, 297.

32. Saraste, A.; Pulkki, K. Cardiovasc. Res. 2000, 45, 528.

33. Kerbel, R. S. Carcinogenesis 2000, 21, 505.

34. Sagar, S. M.; Yance, D.; Wong, R. K. Curr. Oncol. (Toronto, Ont.) 2006, 13, 14. 